\title{
PEMERIKSAAN KEBUNTINGAN SAPI BALI DAN PELAYANAN KESEHATAN HEWAN DI GAPOKTAN NANDA SARI DESA APUAN KECAMATAN SUSUT KABUPATEN BANGLI
}

\author{
I.M. Merdana ${ }^{1}$, I.W. Sudira ${ }^{2}$, K. Budiasa $^{3}$ dan Samsuri ${ }^{4}$
}

\begin{abstract}
ABSTRAK
Pengabdian kepada masyarakat ini bertujuan untuk melakukan pemeriksaan kebuntingan sapi bali dan pelayanan kesehatan hewan di Gapoktan Nanda Sari Desa Apuan, Kecamatan Susut, Kabupaten Bangli. Pengabdian yang telah dilakukan meliputi penyuluhan manajemen pemeliharaan dan kesehatan reproduksi ternak sapi bali, pemeriksaan kebuntingan dan pelayanan kesehatan hewan. Kegiatan penyuluhan diikuti oleh 40 peserta yang terdiri anggota gapoktan dan peternak sekitarnya. Pemeriksaan kebuntingan sapi melalui palpasi rektal dilakukan terhadap tiga ekor induk sapi yang diduga mengalami gangguan reproduksi. Hasil pemeriksaan kebuntingan ditetapkan diagnosa satu ekor induk mengalami patologis korpus luteum persisten dan dua ekor induk kondisi bunting dengan umur kebuntingan 3-4 bulan. Pada pelayanan kesehatan hewan, jumlah ternak yang mendapatkan pelayanan sebanyak 72 ekor sapi, yang terdiri dari 49 ekor induk, 14 ekor pedet betina dan 10 ekor pedet jantan. Ragam pelayanan yang diberikan disesuaikan dengan kebutuhan sapi meliputi injeksi vitamin, pemberian obat cacing, spraying ektoparasit, injeksi antihistamin, injeksi antibiotika dan spraying antibiotika topikal. Dapat disimpulkan bahwa pengabdian ini sangat bermanfaat dalam meningkatkan pengetahuan dan keterampilan peternak serta kepedulian terhadap ternaknya dalam upaya peningkatan produktivitas ternak baik secara kualitas maupun kuantitas.
\end{abstract}

Kata kunci : sapi bali, penyuluhan, pemeriksaan kebuntingan, pelayanan kesehatan hewan

\begin{abstract}
The Community service aims is to carry out pregnancy examination of Bali cattle and animal health services in Gapoktan Nanda Sari Apuan Village, Susut District, Bangli Regency. The services that have been carried out include counseling on cows management and reproductive health of bali cattle, pregnancy examination and animal health services. The counseling activity was attended by 40 participants consisting of Gapoktan members and surrounding farmers. The examination of bali catle pregnancy by rectal palpation was performed on three cows suspected of having reproductive disorders. The results of examination had determined the diagnosis of one cow having persistent corpus luteum and two cows pregnant with 3-4 months of gestation. In animal health services programe, the number of livestock receiving services is 72 cows, consisting of 49 mothers, 14 female calves and 10 male calves. The range of services is provided to the needs of cattle including vitamin injection, giving anthelmintic, ectoparasite spraying, antihistamine injection, antibiotic injection and topical antibiotic spraying. It can be concluded that service is very useful in increasing the knowledge and skills of farmers and caring forthe animals in an effort to increase livestock productivity.
\end{abstract}

Keywords: aaimal health service, bali catle, counseling, pregnancy examination

\footnotetext{
${ }^{1}$ Dosen Fakultas Kedokteran Hewan Universitas Udayana,imade_merdana@unud.ac.id

${ }^{2}$ Dosen Fakultas Kedokteran Hewan Universitas Udayana,wayan.sudira@unud.ac.id

${ }^{3}$ Dosen Fakultas Kedokteran Hewan Universitas Udayana,ketutbudiasa@unud.ac.id

${ }^{4}$ Dosen Fakultas Kedokteran Hewan Universitas Udayana,samsuri@unud.ac.id
} 


\section{PENDAHULUAN}

Secara geografis Desa Apuan, Kecamatan Susut, Kabupaten Bangli ini terletak pada ketinggian 800$1100 \mathrm{~m}$ di atas permukaan laut dengan suhu rata-rata $28^{\circ} \mathrm{C}$. Penduduk desa Apuan sampai dengan tahun 2018 terdiri dari 2.291 laki-laki dan 2.368 perempuan dengan sex ratio 96 serta terdiri dari 1.325 Kepala Keluarga. Sektor pertanian sebagai basis utama mata pencaharian penduduk yang mencapai $80 \%$, termasuk didalamnya sektor peternakan yang tidak terpisahkan dan sudah merakyat yaitu ternak sapi. Ternak sapi bali dengan berbagai kelebihannya berkembang sangat baik dan diminati masyarakat desa. Tercatat ada puluhan petani yang memelihara sapi dan membentuk kelompok-kelompok tani salah satunya yaitu Gapoktan Nanda Sari. Ternak sapi yang dipelihara sekarang ini lebih banyak sapi indukan atau pembibitan. Secara umum masih dipelihara secara tradisional, dan sebagian besar peternak masih merupakan peternak pengadas (sapi milik petani lain) dengan sistem bagi hasil penjualan atau bagi hasil anakan dari keturunan sapi yang dikadas, sehingga kesuksesan reproduksi (menghasilkan anak) menjadi tolak ukur pendapatan peternak pengadas.

Peternak sapi di Desa Apuan secara umum belum memahami dengan benar tujuan beternak sapi dengan manajemen yang baik untuk mendapatkan hasil produksi yang optimal. Banyak faktor yang mempengaruhi keberhasilan dalam beternak sapi bali diantaranya faktor genetik, faktor lingkungan, manajemen pemeliharaan dan faktor penyakit. Faktor genetik berpengaruh terhadap pertumbuhan, dan untuk mendapatkan bibit sapi bali yang baik tentu saja harus berasal dari induk yang unggul. Manajemen pemeliharaan dan manjemen kesehatan ternak yang baik akan menentukan performa akhir yang menguntungkan. Faktor penyakit sangat dipengaruhi tatalaksana pemeliharaan. Beberapa contoh penyakit yang umum menyerang Sapi Bali diantaranya penyakit Bovine Ephimerial Fever (BEF), penyakit SE, Bali Ziekte, colibacilosis dan penyakit parasiter.

Bagi peternak sapi pembibitan atau indukan, faktor kesehatan reproduksi menjadi sangat penting untuk mendapatkan kebuntingan dan kelahiran anak sapi yang tinggi. Banyak peternak yang belum memahami hal ini, mulai dari pemilihan calon induk yang baik, manajemen pemeliharaan induk dan manajemen kesehatan reproduksi secara umum. Kegagalan dalam hal kesehatan reproduksi sudah berarti kerugian karena tidak akan menghasilkan anak sapi. Rendahnya angka kebuntingan setelah dikawinkan merupakan masalah serius bagi peternak, karena menyebabkan rendahnya angka kelahiran yang tentunya akan berdampak pada penurunan populasi. Nitis et al., (2002) melaporkan bahwa keberhasilan inseminasi (IB) masih sangat rendah dan hal ini lebih banyak disebabkan oleh faktor peternak dan Inseminator. Peternak masih kurang pengetahuan dalam mendeteksi tanda birahi (estrus) sehingga waktu pelaksanaan inseminasi yang tidak tepat, tentu akan berpengaruh terhadap keberhasilan kebuntingan. Kurangnya pengetahuan peternak tentang pola beternak sesuai kebutuhan ternak, akan berpengaruh terhadap kesehatan reproduksi. Banyak kasus dilapangan terjadi anestrus postpartus, dan untuk penanganan kasus-kasus reproduksi diperlukan biaya yang cukup tinggi.

Melihat situasi diatas maka sangat penting untuk melakukan pendampingan bagi para peternak dalam upaya peningkatan kapasitas pengetahuan dan ketrampilan beternak sapi bali. Pendampingan yang diperlukan berupa penyuluhan manajemen pemeliharaan dan kesehatan reproduksi ternak sapi, pemeriksaan kebuntingan sapi bali, pelayanan kesehatan hewan dan bimbingan teknis lainnya, sehingga peternak mampu meningkatkan produktivitas dan memperoleh keuntungan yang maksimal. Pengabdian kepada masyarakat ini juga mendukung program pemerintah dalam upaya mencapai swasembada daging nasional melalui kementerian pertanian dalam meningkatkan populasi dan produksi ternak ruminansi besar.

\section{METODE PELAKSANAAN}

Pelaksanaan pengabdian dilakukan dalam dua tahapan yaitu tahap persiapan dan tahap pelaksanaaan. Tahap persiapan meliputi survey lapangan dan persiapan akhir. Survey lapangan bertujuan untuk identifikasi permasalahan yang dihadapi oleh peternak di Gapoktan Nanda Sari. Hasil survey sangat 
penting untuk perencanan program kerja, persiapan akhir alat dan bahan untuk pengabdian. Pada tahap ini juga dilakukan audensi kepada kelompok ternak, kepala desa, tokoh masyarakat, dinas pertanian dan peternakan dan instansi-instansi terkait, untuk keperluan proses perijinan dan fasilitasi pengabdian.

Berdasarkan hasil survey dan identifikasi permasalahan dapat dibuat program kerja pengabdian sebagai berikut; penyuluhan manajemen pemeliharaan ternak sapi, penyuluhan kesehatan reproduksi ternak sapi bali, pemeriksaan kebuntingan sapi dan dilanjutkan dengan pelayanan kesehatan hewan. Ragam pelayanan kesehatan yang diberikan disesuaikan dengan kebutuhan masing-masing individu ternak sapi, diantaranya penyuntikan vitamin, pemberian obat anthelmintik (obat cacing), pengendalian ektoparasit, dan tindakan pengobatan pada sapi yang sakit.

Pelaksanaan Program Udayana Mengabdi (PUM) ini melibatkan 20 orang pengabdi yang terdiri dari staf dosen Fakultas Kedokteran Hewan (FKH), mahasiswa FKH dan mahasiswa KKN PPM Universitas Udayanan Periode XIX yang berlokasi di Desa Apuan, Bangli.

\section{HASIL DAN PEMBHASAN}

\subsection{Penyuluhan manajemen pemeliharaan ternak dan kesehatan reproduksi sapi bali}

Kegiatan pengabdian bertempat di Balai Kelompok Gapoktan Nanda Sari telah dilaksanakan pada tanggal 16 Agustus 2019, yang diikuti oleh 22 orang anggota gapoktan dan 18 peternak sekitarnya. Materi penyuluhan meliputi manajemen pemeliharaan sapi secara umum, manajemen pembibitan, deteksi estrus (birahi), manajemen kawin dan mengenali gangguan reproduksi pada induk sapi. Peternak juga diberikan bimbingan teknis secara langsung dilapangan, seperti cara melihat score body condition induk sapi, pemilihan calon induk, tata kelola kandang dan mengenali kesehatan pedet. Penyuluhan ini bertujuan untuk meningkatkan pengetahuan dan keterampilan beternak sapi sesuai tahapan kebutuhan ternak sapi, dengan harapan angka kebuntingan dan populasi ternak sapi meningkat. Materi disampaikan oleh narasumber yang sekaligus dosen pengabdi dari FKH Unud yaitu Dr. drh. I Wayan Sudira, M.Si, Drh. Ketut Budiasa, MP dan Drh. I Made Merdana, MP., juga dihadiri petugas UPT Kesehatan Hewan dan Peternakan Kecamatan Susut serta petugas pendamping Simantri. Dokumentasi kegiatan penyuluhan seperti pada gambar 1.

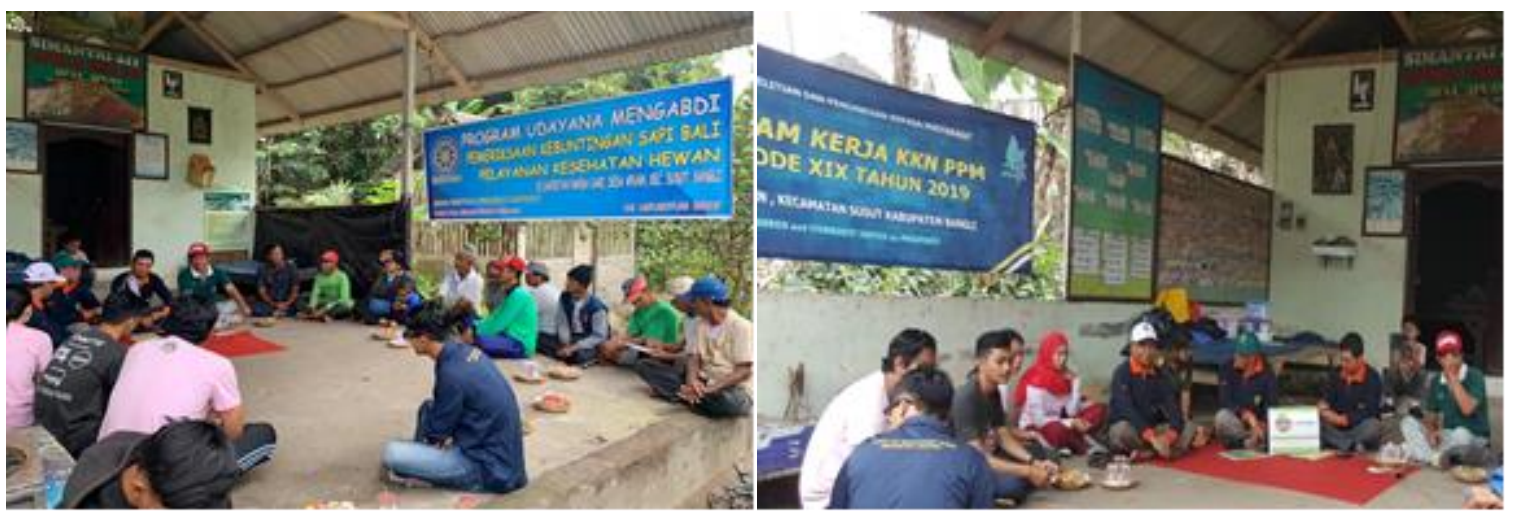

Gambar 1a. Penyuluhan pemeliharaan ternak sapi, dan 1b. Tampak narasumber memaparkan manajemen kesehatan reproduksi ternak sapi

\subsection{Pemeriksaan kebuntingan sapi bali}

Pemeriksaan kebuntingan sapi dilakukan melalui palpasi rektal, bertujuan untuk diagnosa kebuntingan maupun diagnosa kejadian patologis seperti seperti korpus luteum persisten, pyometra, mumifikasi fetus, mucometra, maserasi fetus, tumor, metritis dan mengetahui umur kebuntingan. 
Untuk diagnosa kebuntingan melalui palpasi rektal paling cepat dapat dilakukan setelah umur 90 hari kawin ataupun inseminasi buatan. Kekeliruan penetapan umur kebuntingan sering terjadi karena peternak lupa mencatat tanggal pada saat dilakukan kawin ataupun inseminasi.

Pada pengabdian ini dilakukan pemeriksaan kebuntingan terhadap tiga ekor sapi induk milik peternak yang diduga mengalami gangguan reproduksi. Menurut peternak sapi-sapi tersebut telah dilakukan inseminasi sekitar 3-4 bulan sebelumnya namun masih ragu apakah berhasil bunting atau tidak. Pemeriksaan kebuntingan terhadap sapi milik bapak I Wayan Widia, didiagnosis mengalami korpus luteum persisten sehingga sapi tersebut tidak teramati mengalami bunting maupun tidak mengalami estrus dalam jangka waktu yang lama. Kasus ini memerlukan terapi hormonal supaya siklus estrus induk sapi dapat kembali normal. Untuk itu peternak disarankan untuk menghubungi tenaga medik veteriner di UPT Kesehatan Hewan dan Peternakan Kecamatan Susut ataupun dokter hewan praktek terdekat. Dokumentasi pemeriksaan kebuntingan sapi bapak I Wayan Widia tampak pada gambar 2.
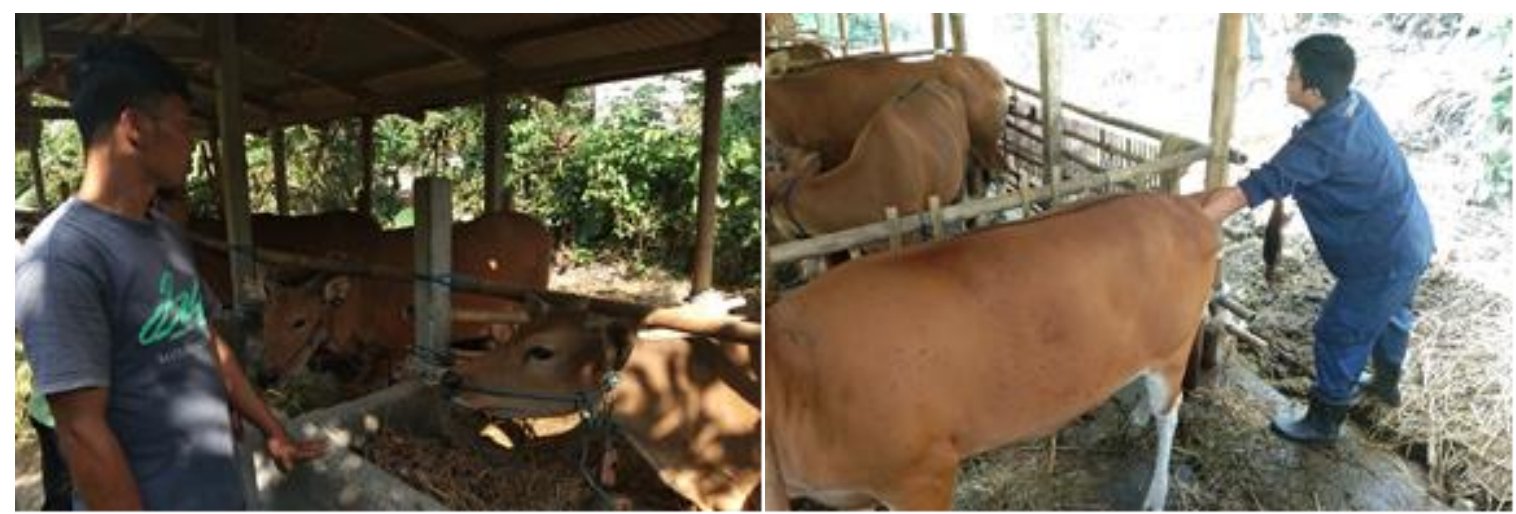

Gambar 2a. Peternak I Wayan Widiya menunjukkan sapi bali betina yang mengalami gangguan reproduksi, dan 2b. Hasil pemeriksaan kebuntingan menunjukkan sapi mengalami corpus luteum persisten

Pemeriksaan kebuntingan terhadap sapi milik bapak I Wayan Sujana dilakukan karena pada pemeriksaan luar belum menunjukkan tanda-tanda bunting, sementara inseminasi sudah dilakukan lebih dari tiga bulan. Setelah dilakukan palpasi rektal dapat ditetapkan diagnosis bahwa sapi tersebut dalam keaadan bunting dengan umur kebuntingan 3-4 bulan. Kejadian yang sama juga dialami oleh peternak I Made Kawat, dimana peternak lupa mencatat tanggal pada saat melakukan inseminasi. Setelah dilakukan pemeriksaan kebuntingan diketahui sapi tersebut dalam keadaan bunting dengan perkiraan umur kebuntingan empat bulan. Dokumentasi pemeriksaan kebuntingan sapi milik kedua peternak tampak pada gambar 3.
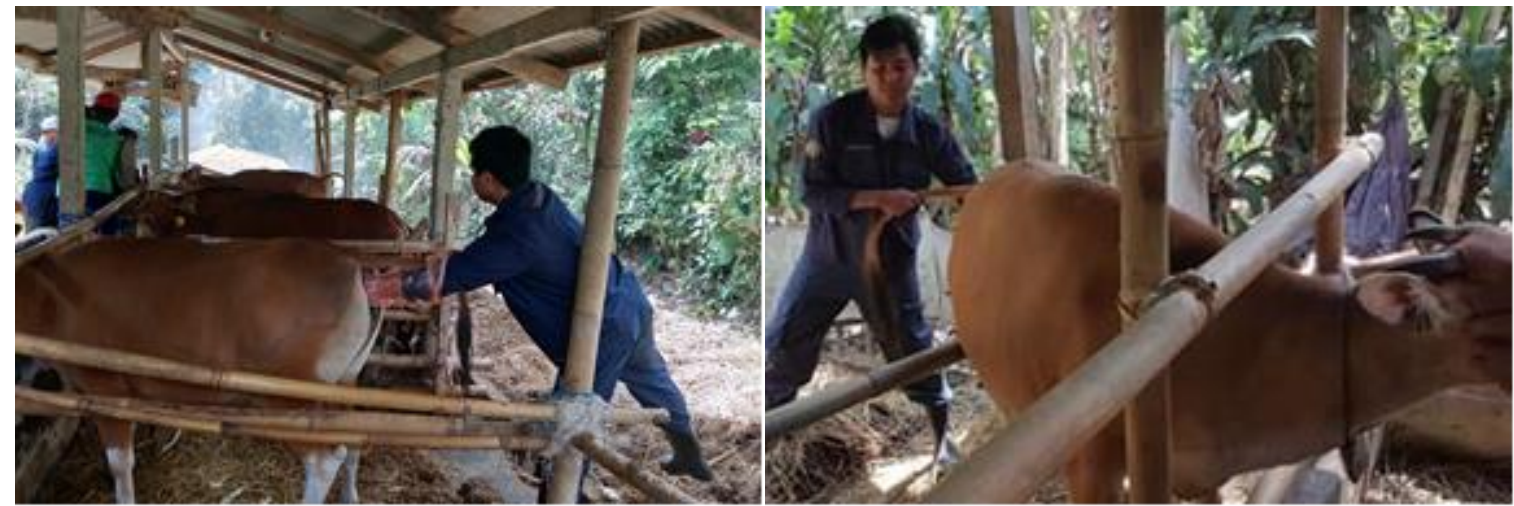

Gambar 3a. Pemeriksaan kebuntingan sapi induk milik I Wayan Sujana diketahui bunting umur 3-4 bulan, dan 3b. Sapi milik I Made Kawat diketahui bunting sekitar 4 bulan 


\subsection{Pelayanan kesehatan hewan}

Kegiatan pelayanan kesehatan hewan meliputi pemberian injeksi vitamin, pemberian anthelmintik (obat cacing), pengendalian ektoparasit (lalat dan kutu), dan pengobatan terhadap sapi yang sakit. Jenis pelayanan kesehatan hewan disesuaikan dengan data yang didapat pada saat melakukan survey lapangan. Pelayanan diberikan pada ternak sapi milik anggota kelompok dan juga milik peternak disekitar lokasi pengabdian. Jumlah ternak yang mendapatkan pelayanan kesehatan sebanyak 72 ekor sapi, yang terdiri dari 49 ekor induk, 14 ekor pedet betina dan 10 ekor pedet jantan (secara rinci disajikan pada Tabel 1).

Pemberian injeksi multivitamin diantaranya Vitamin B Kompleks dan vitamin Neurotropin. Injeksi vitamin diberikan kepada semua ternak sapi dengan dosis sesuai kebutuhan yang telah ditentukan, yaitu untuk induk rata-rata $10-15 \mathrm{ml}$ per ekor dan untuk pedet 5-10 ml per ekor. Pemberian vitamin bertujuan untuk meningkatkan daya tahan tubuh sapi, mengingat kondisi cuaca di bulan Agustus cukup ekstrim dimana akan terjadi peralihan dari musim kemarau menuju musim penghujan. Dokumentasi penyuntikan vitamin oleh tim pengabdi tampak pada Gambar 4a.
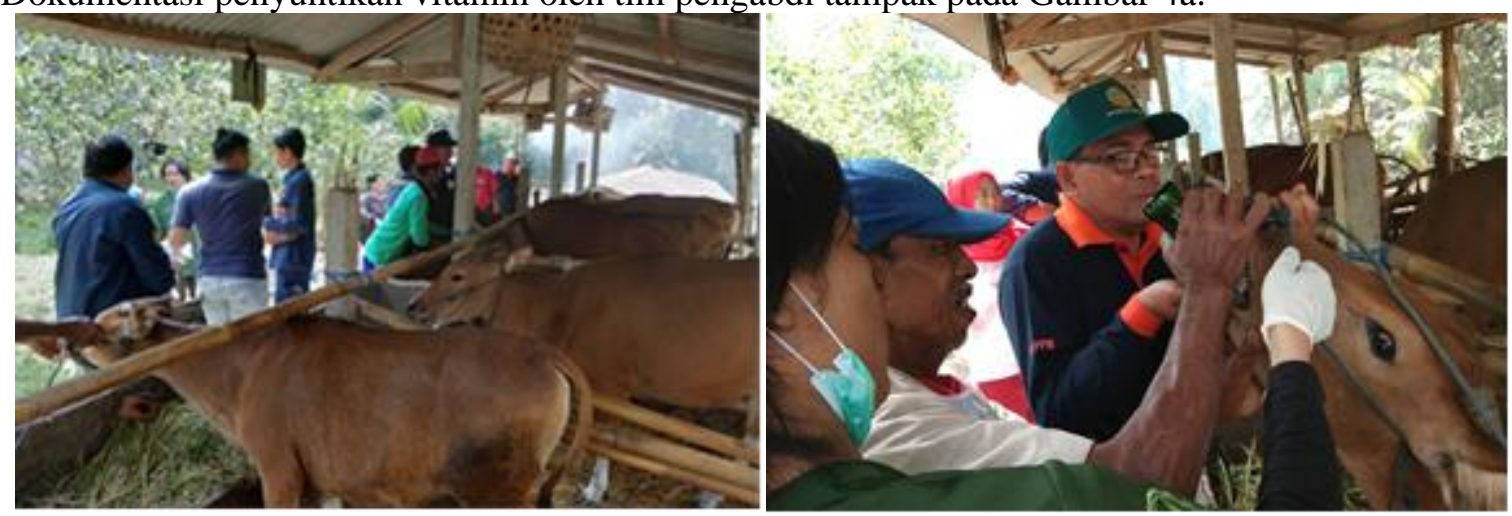

Gambar 4a. Pemberian injeksi vitamin, dan 4b. Peternak praktek memberikan obat cacing

Pelayanan kesehatan berupa pengendalian ektoparasit seperti lalat dan kutu dengan cara spraying antiektoparasit. Bahan kimia yang digunakan adalah deltametrin. Mengingat deltametrin adalah jenis pestisida dan sifatnya yang beracun, peternak diberikan bimbingan teknis supaya berhati-hati untuk keamanan diri sendiri dan ternak saat mengaplikasikannya. Selalu menggunakan sarung tangan atau minimal menggunakan kantung plastik untuk mencegah kontak langsung dengan pestisida. Pada saat penyemprotan harus berhati-hati supaya tidak mengenai bagian mulut, hidung sapi, menghindari bagian putting bila sedang menyusui, dan juga tidak mencemari pakan sapi supaya tidak terjadi keracunan. Pada gambar 5a ditampilkan cara melakukan spraying yang benar oleh mahasiswa koasistensi FKH Unud.
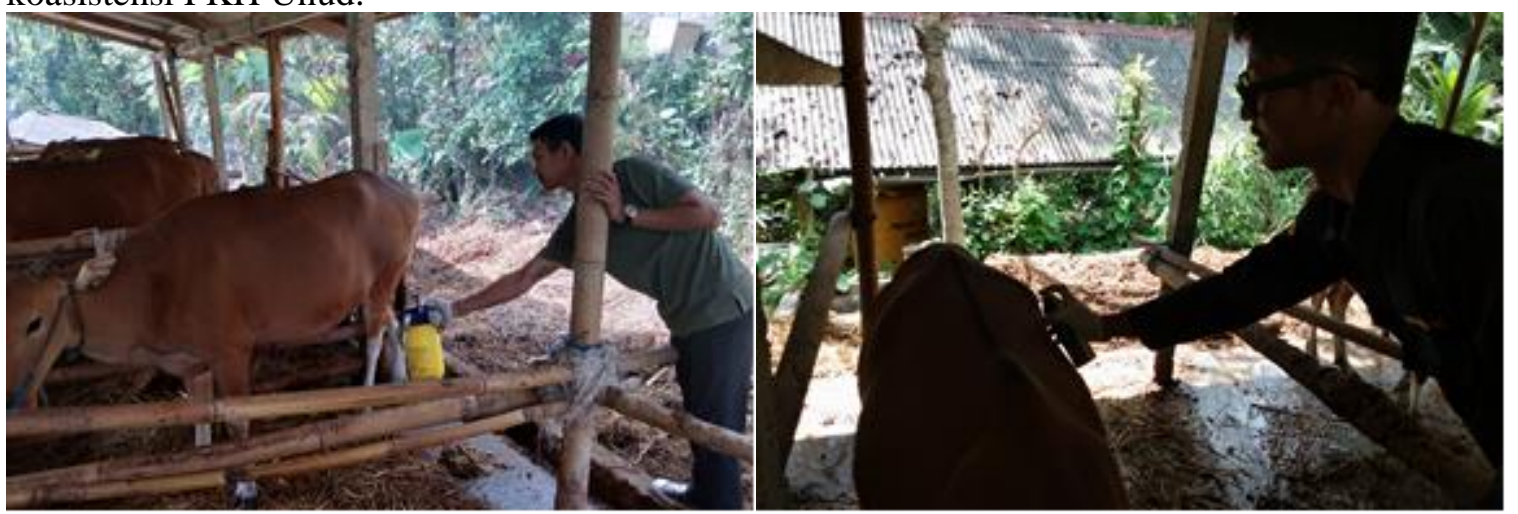

Gambar 5a. Spraying anti ektoparasit, dan 5b. Spraying obat topikal terhadap lesi kulit sapi Tindakan pengobatan selain pelayanan kesehatan diatas dilakukan terhadap dua ekor pedet yang mengalami penyakit bali ziekte. Terhadap kedua pedet diberikan injeksi antihistamin dan 
antibiotika, dan juga pengobatan topikal pada lesi kulit dengan cara spraying menggunakan obat yang mengandung antibiotika oxytetraciclin, seperti pada gambar $5 \mathrm{~b}$.

Tabel 1. Rekapitulasi data peternak, jumlah ternak dan ragam pelayanan kesehatan hewan

\begin{tabular}{|c|l|l|c|l|}
\hline No & \multicolumn{1}{|c|}{ Peternak } & \multicolumn{1}{|c|}{ Jenis Ternak } & $\begin{array}{c}\text { Jumlah } \\
\text { (ekor) }\end{array}$ & \multicolumn{1}{|c|}{ Pelayanan yang diberikan } \\
\hline 1 & I Nyoman Kartika & Sapi Induk & 2 & Injeksi vitamin, obat cacing \\
\hline 2 & I Made Kawat & Sapi Induk bunting & 2 & $\begin{array}{l}\text { Injeksi vitamin, pemeriksaan } \\
\text { kebuntingan (bunting 3-4 bulan) }\end{array}$ \\
\hline 3 & Nyoman Kasna & Sapi Induk \& pedet & 3 & Injeksi vitamin, obat cacing \\
\hline 4 & Wayan Sujana & Sapi Induk \& pedet & 4 & $\begin{array}{l}\text { Injeksi vitamin, pemeriksaan } \\
\text { kebuntingan (bunting 3-4 bulan) }\end{array}$ \\
\hline 5 & Wayan Guna & Pedet & 2 & $\begin{array}{l}\text { Injeksi vitamin, obat cacing, } \\
\text { gusanex }\end{array}$ \\
\hline 6 & Wayan Widiya & Sapi Induk bunting & 2 & $\begin{array}{l}\text { Injeksi vitamin, pemeriksaan } \\
\text { kebuntingan (kasus CLP) }\end{array}$ \\
\hline 7 & Nyoman Suanda & Sapi Induk & 2 & Injeksi vitamin \\
\hline 8 & Nyoman Nyawang & Sapi Induk \& pedet & 4 & Injeksi vitamin, obat cacing \\
\hline 9 & Nyoman Rantar & Sapi Induk \& pedet & 2 & $\begin{array}{l}\text { Injeksi vitamin, pemeriksaan } \\
\text { kebuntingan (bunting 3-4 bulan) }\end{array}$ \\
\hline 10 & Wayan Wenten & Sapi Induk \& pedet & 3 & Injeksi vitamin \\
\hline 11 & I Wayan Serija & Sapi Induk & 3 & Injeksi vitamin, obat cacing \\
\hline 12 & I Made Kamar & Sapi Induk bunting & 2 & Injeksi vitamin \\
\hline 13 & I Nyoman Suparda & Sapi Induk & 2 & Injeksi vitamin, obat cacing \\
\hline 14 & I Nyoman Kantor & Sapi Induk \& pedet & 6 & Injeksi vitamin, obat cacing \\
\hline 15 & I Made Sutama & Sapi Induk bunting \& pedet & 4 & Injeksi vitamin \\
\hline 16 & Made Payu & Sapi Induk bunting & 2 & Injeksi vitamin \\
\hline 17 & Wayan Tarka & Sapi Induk \& pedet & 5 & Injeksi vitamin, obat cacing \\
\hline 18 & I Kadek Puja & Sapi Induk \& pedet & 4 & $\begin{array}{l}\text { Injeksi vitamin, antihistamin, } \\
\text { antibiotika, obat cacing }\end{array}$ \\
\hline 19 & Ketut Mudiasa & Sapi Induk bunting \& pedet & 4 & Injeksi vitamin, obat cacing \\
\hline 20 & I Nym Adi Darmaja & Sapi Induk & 2 & Injeksi vitamin, obat cacing \\
\hline 21 & I Wayan Tata & Sapi Induk \& pedet & 4 & $\begin{array}{l}\text { Injeksi vitamin, pemeriksaan } \\
\text { kebuntingan (bunting 3-4 bulan) }\end{array}$ \\
\hline 22 & I Ketut Ada & Sapi Betina & 3 & Injeksi vitamin, obat cacing \\
\hline & & & & \multicolumn{1}{|c|}{ Total } \\
\hline
\end{tabular}

\section{KESIMPULAN DAN SARAN}

Kegiatan pengabdian masyarakat kepada peternak sapi di Gapoktan Nanda Sari sangat bermanfaat dalam meningkatkan pengetahuan dan keterampilan beternak sapi serta meningkatkan kesehatan ternak sapi dalam upaya peningkatan produktivitas baik secara kualitas maupun kuantitas.

Kegiatan pengabdian masyarakat yang serupa, diharapkan dapat diselenggarakan secara periodik dengan menyasar kelompok-kelompok tani ternak yang belum mendapatkan pendampingan.

\section{UCAPAN TERIMA KASIH}

Penulis mengucapkan terima kasih kepada Rektor, Ketua LPPM dan Dekan Fakultas Kedokteran Hewan Universitas Udayana atas pendanaan pengabdian melalui DIPA PNBP Universitas Udayana Tahun 2019, No SPK: 552-66/UN14.4.A/PM/2019 tanggal 10 April 2019.

\section{DAFTAR PUSTAKA}


Agung, O.A, I.N. T. Ariana, N.L.P. Sriyani, M. Dewantari Dan N.P. Sarini. 2015. Upaya Meningkatkan Produktifitas Sapi Bali Melalui Manipulasi Teknologi Pemberian Pakan Berbasis Hijauan. Denpasar. Universitas Udayana.

https://simdos.unud.ac.id/uploads/file_penelitian_1 dir/bd9688bc0d0fbc758cdac6f0d6a399c7.pdf

Batan, IW. 2002. Buku Ajar Sapi Bali dan Penyakitnya. Denpasar : Universitas Udayana

Nitis, I.M., K. Lana, W. Sukanten , T.G.O. Pemayun dan A.W. Puger, 2000. Reproduksi Sapi Bali pada sistem Tiga strata di daerah Tingkat II Badung; Penampilan reproduksi ke -4. Fapet Unud. Denpasar. hal.18.

Pemayun, T.G.O., 2006. Kadar Prostaglandin F2 $\alpha$ dari cairan vesikula seminalis,produk sel monolayer vesikula seminalis dan endometrium Sapi Bali serta bioaktivitasnya, Disertasi Pasca Sarjana Unair.

Ni'am, H.U.M., Purnomoadi, A. dan Dartosukarno, S. 2012. Hubungan Antara Ukuran-ukuran Tubuh Dengan Bobot Badan Sapi Bali Betina Pada Berbagai Kelompok Umur. Animal Agriculture Journal, 1(1), 541-556.

Tim Pusat Kajian Sapi Bali. 2012. Sapi Bali Sumberdaya Genetik Asli Indonesia. Denpasar. Universitas Udayana.

LPPM UNUD. 2017. Panduan Penelitian dan Pengabdian Kepada Masyarakat Edisi XI Tahun2017. Denpasar. Universitas Udayana. 